\title{
PELATIHAN BATIK CELUP DI GAMPONG JANTHO
}

\author{
Miftahun Naufa $^{1 *}$, Niko Andeska ${ }^{2 *}$, Anni Kholilah ${ }^{3 *}$ \\ Jurusan Seni Rupa dan Desain \\ Institut Seni Budaya Indonesia (ISBI) Aceh \\ Jl. Transmigrasi, Gampong Bukit Meusara, Kec. Kota Jantho, Kab. Aceh Besar, 23911. \\ Aceh. Indonesia \\ Email: miftahunnaufa@isbiaceh.ac.id
}

\begin{abstract}
Abstrak
Jantho merupakan sebuah daerah dengan dataran tinggi yang menjadi ibu kota Aceh Besar, kota Jantho menjadi pusat kota dan menjadi pusat pemerintahan serta administrasi untuk daerah Aceh Besar, meskipun kota Jantho menjadi pusat administrasi, tetapi kota Jantho masih dominan dengan daerah perhutanan dan perbukitan. Gampong Jantho memiliki sumber daya alam yang besar namun belum dapat termanfaatkan secara maksimal oleh masyarakat dan pemerintah Aceh Besar. Melihat sumber daya alam yang besar menjadi ide dan daya tarik untuk mengolahnya sehingga dapat meningkatkan perekonomian daerah tersebut. Permasalahan yang ada di Gampong Jantho adalah kurangnya pembinaan dalam sektor pembuatan kerajinan. Dengan terselenggaranya pengabdian masyarakat diharapkan dapat menambah dan mengembangkan wawasan masyarakat untuk membuat karya yang memiliki nilai jual. Salah satu upaya yang ingin dikembangkan adalah membuat kerajinan batik celup, batik celup merupakan satu kerajinan batik yang sangat mudah dipelajari dan dapat dimanfaatkan untuk meningkatkan sektor perdagangan masyarakat setempat.
\end{abstract}

Kata Kunci: batik celup, gampong jantho.

\begin{abstract}
Jantho is a highland area which is the capital of Aceh Besar, Jantho city is the center of the city and the administrative and administrative center for the Greater Aceh area, although Jantho city is the administrative center, but Jantho city is still dominant in forest and hilly areas. Gantong Jantho has large natural resources but cannot be fully utilized by the community and the government of Aceh Besar. Seeing large natural resources is an idea and attraction to process them so that they can improve the economy of the area. The problem that exists in Jantho Village is the lack of guidance in the craft making sector. With the implementation of community service, it is expected to be able to add and develop community insight to create works that have a sale value. One of the efforts to be developed is to make dyed batik, batik dye is a batik craft that is very easy to learn and can be used to improve the local community's trade sector.
\end{abstract}

Keywords: batik dyes, gampong jantho.

\section{PENDAHULUAN}

Sesuai dengan salah satu Tri Dharma Perguruan Tinggi yakni pengabdian kepada masyarakat, maka dengan ini Institut Seni Budaya Indonesia Aceh memiliki peran yang sangat penting dan bertanggungjawab dalam upaya peningkatan kemampuan masyarakat, khususnya di bidang seni. Salah satu peran Institut Seni Budaya Indonesia Aceh untuk meningkatkan kemampuan masyarakat di bidang seni yaitu melalui kegiatan pengabdian kepada masyarakat. Oleh karena itu kami telah menentukan obyek pengabdian kepada masyarakat atau pelatihan ini yaitu masyarakat Gampong Jantho, Kota Jantho, Aceh Besar, Aceh.
Gampong Jantho merupakan salah satu dari 13 desa yang terdapat di Kota Jantho, Kabupaten Aceh Besar, Provinsi Aceh. Obyek ini di nilai sangat tepat dilakukan kegiatan Pelatihan Batik Celup. Mengingat situasi dan kondisi yang terdapat di daerah tersebut yang masih minimnya pelatihan, serta kurangnya keterampilan khususnya di bidang seni.

Batik Celup memiliki prospek yang sangat baik dikarenakan dapat bermanfaat bagi masyarakat untuk kebutuhan sehari-hari. Bahkan dapat menjadi pekerjaan sampingan untuk menambah penghasilan masyarakat seperti alas meja, kaos, sarung bantal, seprai dan lainnya. 


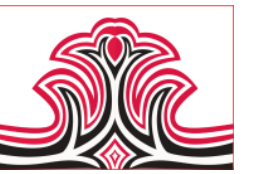

Selain itu, sasaran lain yang ingin dicapai adalah menjadikan Gampong Jantho sebagai desa home industry sehingga dapat menjadi desa percontohan bagi desa lainya. Pada tahap awal ini media yang digunakan untuk Pelatihan Batik Celup adalah sapu tangan dan kaos dengan pewarnaan napthol, dikarenakan bahan-bahan yang digunakan cukup praktis dan masih mudah dijangkau.

\section{KAJIAN TEORI}

Upaya peningkatan kemampuan masyarakat khususnya di bidang seni, perlu melakukan pelatihan khusus. Salah satu pelatihan yang efisien kepada masyarakat yaitu melalui pelatihan batik celup.

Batik adalah kain bergambar yang pembuatannya secara khusus dengan menuliskan atau menerakan malam pada kain itu, kemudian pengolahannya diproses dengan cara tertentu, sedangkan membatik adalah membuat corak atau gambar (terutama dengan tangan) dengan menerakan malam pada kain. Batik dalam Bahasa Jawa berarti tulis, secara mudah kemudian diartikan melukis dengan lilin (Susanto : 21). Batik celup adalah teknik mewarnai kain dengan cara mengikat kain dengan cara tertentu sebelum dilakukan pencelupan. Di beberapa daerah di Indonesia, teknik ini dikenal dengan berbagai nama lain seperti pelangi atau cinde, tritik atau jumputan, serta sasirangan.

Membatik pada hakikatnya sama dengan melukis di atas kain dengan menggunakan canting sebagai alatnya dan cairan malam sebagai bahan untuk melukisnya. Seni batik adalah seni budaya yang kaya nilai-nilai kehidupan manusia dan lingkungan. Artinya dalam seni batik orang akan merasakan denyut nadi dari semangat bangsa Indonesia dari keyakinannya, pandangan hidupnya, dan tujuan masa depannya.

\section{METODE PENELITIAN}

Metode pelaksanaan kegiatan pelatihan batik celup yang akan dilaksanakan menggunakan pendekatan participant active lerning, yaitu peserta berperan aktif dalam pelatihan batik celup yang di laksanakan. Tahapan pada metode pelatihan ini terdiri atas:

\section{Demonstrasi}

Demonstrasi dilakukan dengan memberikan contohcontoh produk batik celup yang telah di buat sebelumnya.

\section{Tanya Jawab}

Tanya jawab dilakukan setelah pemberian penjelasan kepada obyek pelatihan.
Gorga : Jurnal Seni Rupa

Volume 08 Nomor 02 Juli-Desember 2019 p-ISSN: 2301-5942 | e-ISSN: 2580-2380

\section{Praktek}

Praktek merupakan kegiatan pelatihan yang di berikan kepada peserta sebagai follow up dari penjelasan yang telah disampaikan sebelumnya.

\section{Evaluasi}

Evaluasi pada kegiatan ini dilakukan untuk meninjau kembali yang telah di lakukan.

\section{HASIL DAN PEMBAHASAN}

\section{Hasil}

Kegiatan pelatihan batik celup di Gampong Jantho dilaksanakan pada hari minggu tanggal 14 September 2019, dimulai dari pukul 10:00 wib hingga pukul 16:00 wib. Pelatihan tersebut memfokuskan ibu-ibu dan remaja putri sebagai peserta dengan target peserta sebanyak 25 orang, akan tetapi antusias masyarakat yang sangat tinggi terhadap pelatihan tersebut sehingga jumlah peserta menjadi 35 orang yaang terdiri atas ibu-ibu, pemudi, dan anak-anak.

\section{Pembahasan}

Pelatihan diawali dengan pemberian materi singkat tentang defenisi batik celup, ruang lingkup, bahan, dan tekniknya. Serta memperagakan contoh hasil dari batik celup seperti kaos dan sapu tangan yang telah di persiapkan sebelumnya.

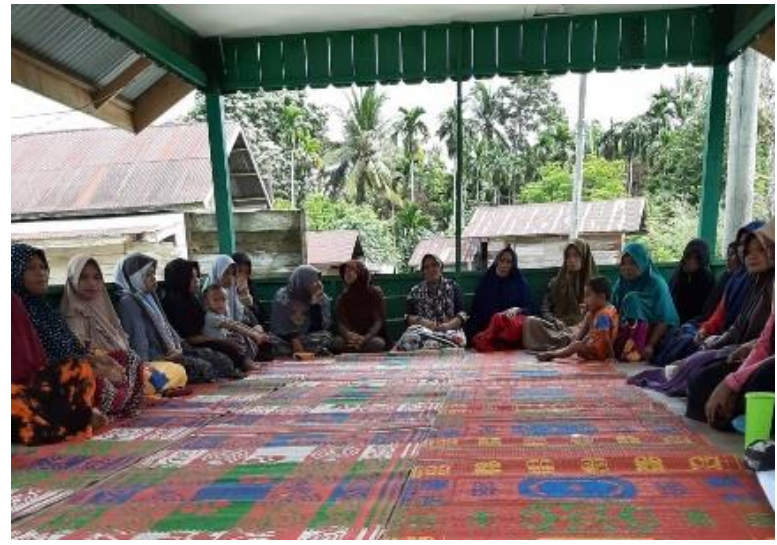

Gambar 1. Pemaparan Materi dari Tim Pelaksana (Sumber: Anni Kholilah, 2019)

\section{1). Pembuatan Sapu Tangan Batik Celup}

Pada proses pembuatan sapu tangan batik celup, diawali dengan tahap pengikatan kain menggunakan karet dan benang serta melipat kain, dengan tujuan pembetukan motif. 


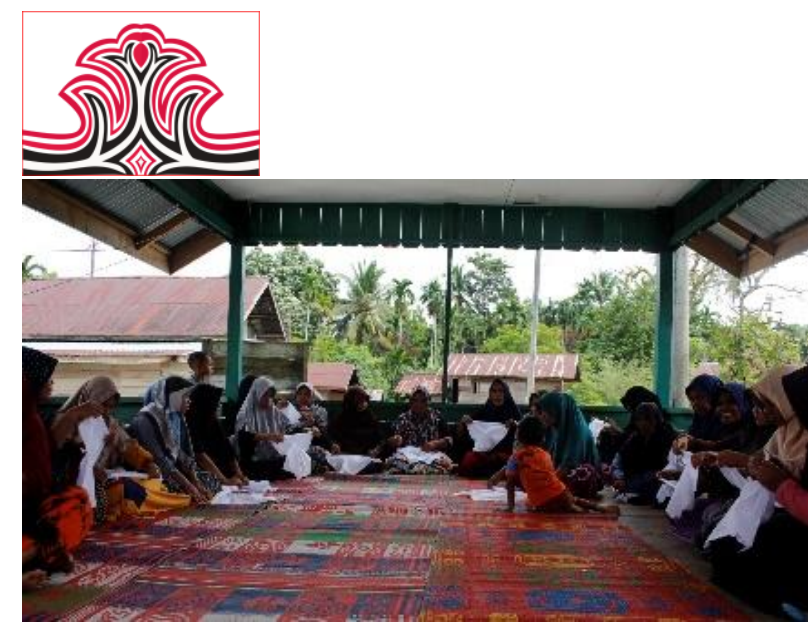

Gambar 2. Tahap Mengikat atau Melipat Kain (Sumber: Anni Kholilah, 2019)

Tahap selanjutnya peserta diperagakan proses mempersiapkan pewarna batik sebelum di gunakan. Pewarna batik yang digunakan pada pelatihan batik celup ini yaitu Napthol.
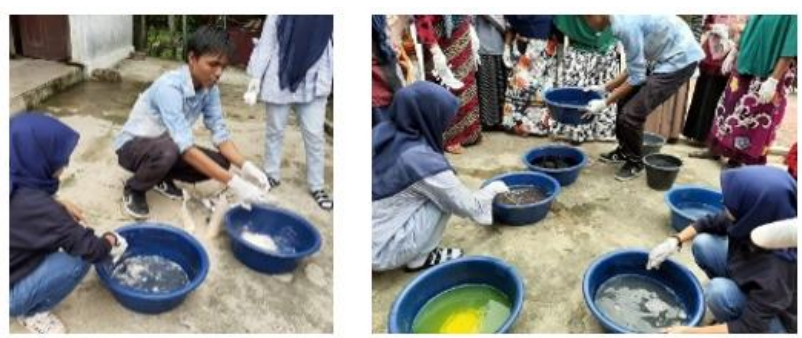

Gambar 3. Persiapan Pewarnaan (Sumber: Anni Kholilah, 2019)

Kemudia peserta melakukan pencelupan pada pewarna batik yang telah di persiapkan dengan di dampingi oleh instruktur.

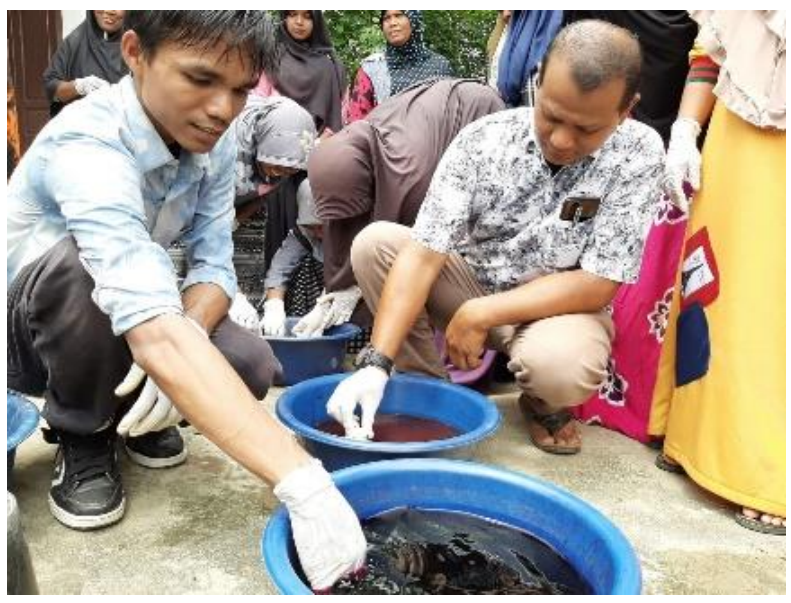

Gambar 4. Tahap Pencelupan (Sumber: Anni Kholilah, 2019)

\section{2). Pembuatan Baju Kaos Batik Celup}

Pada proses pembuatan baju kaso batik celup, sama halnya dengan pembuatan sapu tangan batik celup. Akan tetapi pada proses yang kedua ini, peserta lebih antusias dan serius dalam mengikutinya, hal ini dapat
Gorga : Jurnal Seni Rupa

Volume 08 Nomor 02 Juli-Desember 2019 p-ISSN: 2301-5942 | e-ISSN: 2580-2380

terlihat dari beberapa ibu-ibu dan anak-anak membawa jilbab putih dari rumah masing-masing.

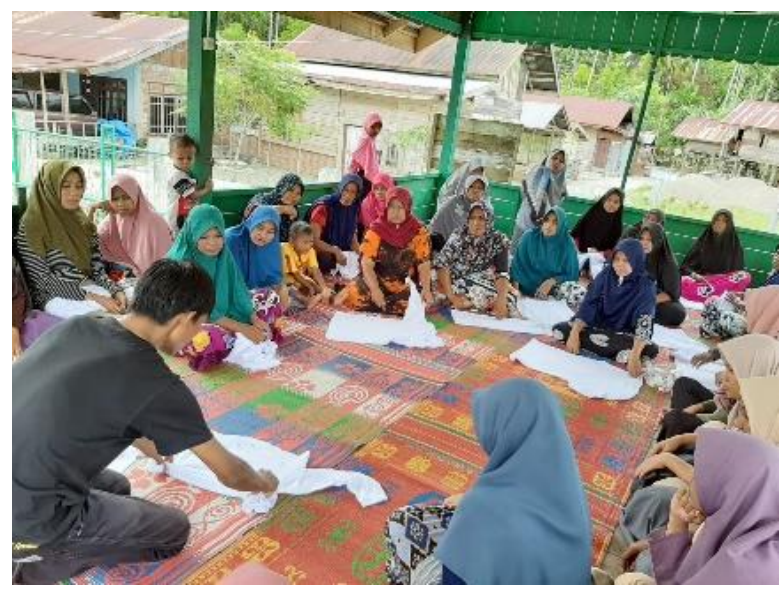

Gambar 5. Tahap Mengikat atau Melipat Kain (Sumber: Anni Kholilah, 2019)

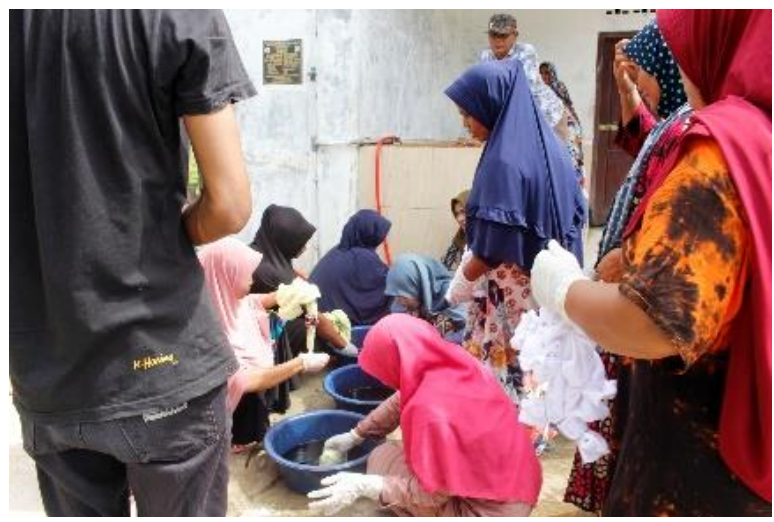

Gambar 6. Proses Pencelupan Baju Kaos dan Disaksikan oleh Sekretaris Gampong Jantho

(Sumber: Anni Kholilah, 2019)

Beberapa dokumentasi hasil pelatihan sebagai berikut:

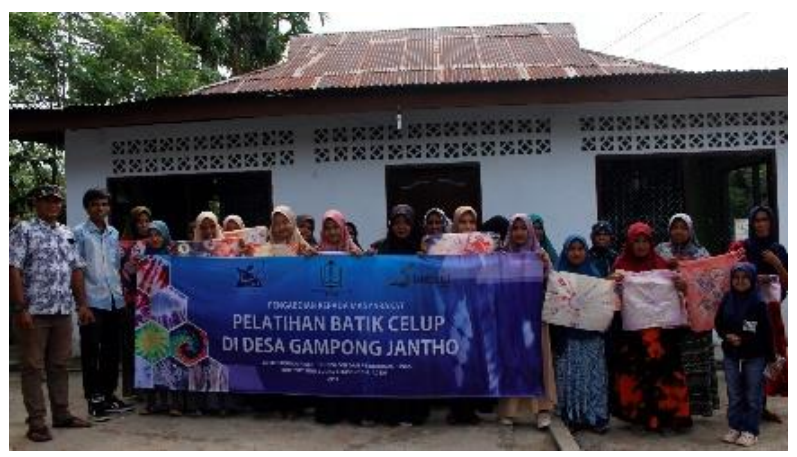

Gambar 7. Foto Bersama Peserta Pelatihan dan Sekretaris Gampong Jantho dengan Memegang Sapu Tangan Batik Celup (Sumber: Anni Kholilah, 2019) 


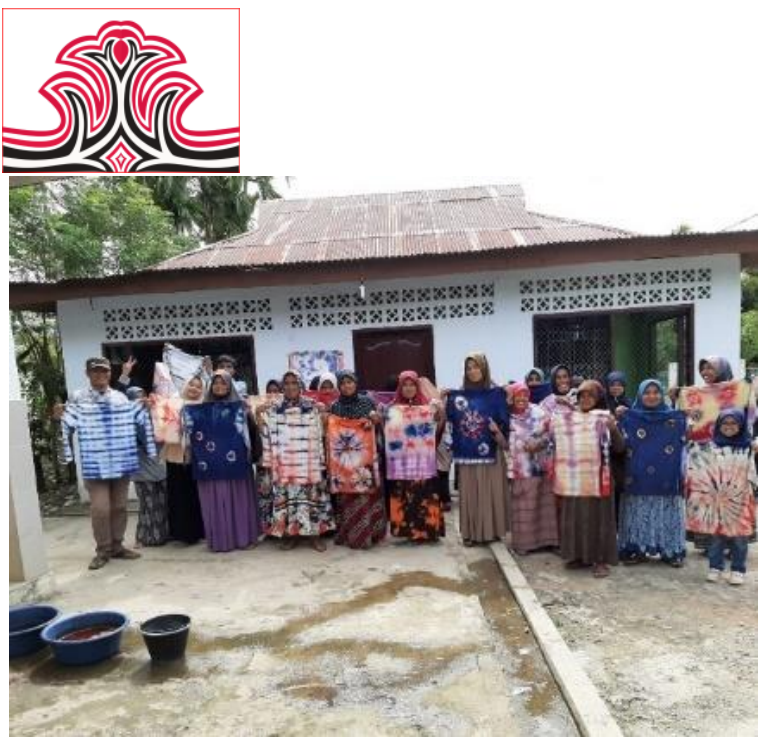

Gambar 8. Foto Bersama Peserta Pelatihan dan Sekretaris Gampong Jantho dengan Memegang Baju Kaos Batik Celup (Sumber: Anni Kholilah, 2019)

\section{KESIMPULA DAN SARAN}

\section{Kesimpulan}

Negara Indonesia merupakan salah satu negara terkaya akan budaya, kesenian serta kerajinan, setiap daerah memiliki karakter dan bentuk masing-masing dari karya seni dan budaya. Sama halnya dengan daerah Aceh, Aceh merupakan wilayah yang kaya akan hasil bumi dan budaya serta memiliki berbagai macam jenis kerajinan yang merupakan peninggalan turun temurun dari leluhur masyarakat Aceh pada masa lampau. Namun sebagian dari kerajinan tersebut masih belum bisa dimanfaatkan masyarakat untuk mensejahterakan hidup mereka, maka untuk itu sesuai dengan Tri Darma Perguruan Tinggi yaitu pengabdian kepada masyarakat, ISBI Aceh merupakan sebuah Lembaga Pendidikan yang bidang ilmunya terfokus pada budaya dan kesenian punya kewajiabna untuk memberikan pengetahuan dan pengalaman untuk perkembangan kesenian serta kerajinan seni rupa di daerah Aceh. Melalui Lembaga Penelitian Pengabdian Masyakat dan Penjaminan Mutu Pendidikan diharapkan dapat melahirkan karya-karya dengan konsep daerah setempat yang kemudian dikelola secara apik dalam bentuk tulisan maupun karya seni yang bermanfaat bagi penduduk setempat.

\section{Saran}

Pengabdian kepada masyarakat dengan judul "Pelatihan Batik Celup Di Gampong Jantho" diharapkan menjadi salah satu wadah untuk menjalin kerjasama dengan masyarakat dan membentuk kelompok dalam pengembangan kerajinan di Gampong Jantho Aceh Besar.

\section{DAFTAR RUJUKAN}

Susanto, Mikke. (2002). Diksi Rupa. Yogyakarta:

Kanisius. 